\title{
Isolation and Partial Characterization of a Trypsin Inhibitor from Wheat Endosperm
}

\author{
Toshio Mitsunaga, Yuko Kimura, and Mayumi Shimizu ${ }^{1}$ \\ Department of Food Science, Faculty of Home Economics, \\ Kyoto Women's University, \\ Imakumano, Higashiyama-ku, Kyoto 605, Japan
}

(Received December 28, 1981)

\begin{abstract}
Summary Trypsin inhibitors were isolated from wheat endosperm, and a major inhibitor (wheat endosperm trypsin inhibitor-I, WETI-I) was purified by ion-exchange chromatographies on CM-Sephadex and SPSephadex, gel filtration on Sephadex G-75 and chromatofocusing on Polybuffer exchanger PBE 94. This inhibitor was a polypeptide composed solely of amino acids, and its $\mathrm{p} I$ value was 9.35 . It was found to be homogeneous in gel electrophoresis and velocity sedimentation. It showed strong inhibition on bovine trypsin but weak inhibition on bovine $\alpha$ chymotrypsin. The molecular weight of the inhibitor was approximately 7,800 as judged from SDS-gel electrophoresis. This finding, along with the trypsin inhibition data, suggested that the inhibitor bound trypsin in the molar ratio of $1: 1$. Certain other properties of the inhibitor, including amino acid composition and UV spectral characteristics are presented.

Key Words trypsin inhibitor, wheat endosperm, chromatofocusing, isoelectric point, gel electrophoresis, velocity sedimentation
\end{abstract}

The occurrence of protease inhibitors in wheat grain has been demonstrated by many workers (1-4). Shyamala et al. (5) isolated a heat-labile trypsin inhibitor from whole wheat flour by ammonium sulfate precipitation and chromatography on CMcellulose. Hochstrasser and Werle (6) purified a trypsin inhibitor with a molecular weight of 17,000 from wheat germ and characterized it in terms of its chemical and physicochemical properties. Recently Chang et al. (7) isolated two trypsin inhibitors from red winter wheat and durum wheat, respectively, by affinity chromatography. They gave certain information on the characterization and heat stability of them $(8)$. In our laboratory, several protease inhibitors have been detected in three portions of wheat grain, germ, bran and endosperm (9). Furthermore, two trypsin inhibitors (WGTI-I, WGTI-II) (10) and a trypsin inhibitor (WBTI-I) (11) have been purified from wheat germ and bran, respectively.

\footnotetext{
1 光永俊郎，木村祐子，清水まゆみ
} 
In this paper, the isolation and certain properties of the trypsin inhibitor in wheat endosperm are described.

\section{MATERIALS AND METHODS}

\section{Materials}

Hard wheat endosperm of the Canada Western variety was kindly supplied by Nisshin Milling Ltd. Trypsin [EC 3.4.21.4] ( $2 \times$ cryst., from bovine pancreas $)$ and $\alpha$ chymotrypsin [EC 3.4.21.1] ( $3 \times$ cryst., from bovine pancreas) were the products of Sigma Chemical Co. $\alpha$ - $N$-Benzoyl-D,L-arginine- $p$-nitroanilide (BANA), a substrate of trypsin, was purchased from the Protein Research Foundation. Sephadex G-75, CM-Sephadex C-25, SP-Sephadex C-25, Polybuffer exchanger PBE 94 and Pharmalyte were purchased from Pharmacia Fine Chemicals Co. The molecular weight marker proteins and $p$-nitrophenyl- $p^{\prime}$-guanidinobenzoate hydrochloride were obtained from Sigma Chemical Co. Carrier ampholyte was obtained from LKB. All other reagents used were of reagent grade.

\section{Methods}

Chemical analyses. Protein was determined by the Lowry-Folin method(12) using ovalbumin as a reference, or by the micro-Kjeldahl method(13). Carbohydrate was determined by the phenol-sulfuric acid method (14).

Amino acid analysis. The sample was hydrolyzed with constant-boiling $\mathrm{HCl}$ at $105^{\circ} \mathrm{C}$ in vacuum-sealed tubes for 24,48 and $72 \mathrm{hr}$. Analyses were carried out using an automatic amino acid analyzer, Hitachi model KLA-835. Tryptophan and tyrosine contents were determined by the method of Goodwin and Morton(15).

Assay of protease activities and inhibitory activity. The hydrolytic activity of trypsin was measured by the modified method(10) of Erlanger et al.(16) using BANA as substrate.

The proteolytic activities of trypsin and $\alpha$-chymotrypsin were measured by the casein digestion method (17).

The inhibitory activity was estimated from the residual protease activity in the reaction mixture incubated with the inhibitor, and expressed as percent inhibition (I) of the control activity using the following equation:

$$
I(\%)=100\left(T-T^{*}\right) / T
$$

where $T^{*}$ and $T$ are the activities of protease with and without the inhibitor, respectively. The inhibitor unit was defined as the amount of inhibitor required for the complete inhibition of $1 \mu \mathrm{g}$ of active trypsin. The purity of the trypsin used was determined by active site titration using $p$-nitrophenyl- $p^{\prime}$-guanidinobenzoate hydrochloride (18), and a value of $70 \%$ was obtained.

In routine assays BANA was used as substrate.

Velocity sedimentation. Analytical ultracentrifugation was carried out in a Spinco model E ultracentrifuge equipped with Schlieren optics. The experiment was 
run at $59,780 \mathrm{rpm}$ in $0.1 \mathrm{M}$ Tris- $\mathrm{HCl}$ buffer, $\mathrm{pH} 8.0$, containing $0.1 \mathrm{M} \mathrm{KCl}$ at $20^{\circ} \mathrm{C}$. The sedimentation coefficient was calculated from the rate of movement of the maximum ordinate position of the Schlieren pattern.

Gel electrophoresis. Disc gel electrophoresis was carried out as described by Reinsfeld et al. (19) on $10 \%$ polyacrylamide gel in $\beta$-alanine-acetic acid buffer ( $\mathrm{pH}$ 4.5). SDS-gel electrophoresis was performed, in the presence of $1 \% \mathrm{SDS}$, on $10 \%$ polyacrylamide gel in $0.1 \mathrm{M}$ sodium phosphate buffer $(\mathrm{pH} 7.1)$. The procedure described by Shapiro et al. (20) was followed to prepare the gel column, and the electrophoresis was run at a constant current of $8 \mathrm{~mA} /$ column at room temperature. The gels were stained for protein with $1 \%$ Amido Black $10 \mathrm{~B}$ in a $25 \%$ isopropyl alcohol solution containing $7 \%$ acetic acid.

For estimation of molecular weight, the samples and molecular weight marker proteins were incubated in $0.01 \mathrm{M}$ sodium phosphate buffer $(\mathrm{pH} 7.1)$ containing $1 \%$ SDS and $1 \%$ 2-mercaptoethanol at $60^{\circ} \mathrm{C}$ for $2 \mathrm{hr}$, prior to SDS-gel electrophoresis $(21)$.

Isoelectric focusing. The sample was subjected to isoelectric focusing in a thin layer of polyacrylamide gel, using LKB 2117 Multiphor equipment.

\section{RESULTS}

\section{Extraction and separation of trypsin inhibitors}

The endosperm powder was ground thoroughly with the aid of sea sand wetted with $0.1 \mathrm{M} \mathrm{NaCl}$ solution in a mortar. Then, $0.1 \mathrm{M} \mathrm{NaCl}$ solution (of a weight 10 -fold that of the endosperm) was added to the resulting paste, the mixture was allowed to stand for $2 \mathrm{hr}$ at room temperature, and was then filtered through glass wool to obtain a clear extract. The extract was heated at $60^{\circ} \mathrm{C}$ for $10 \mathrm{~min}$ to precipitate heat-

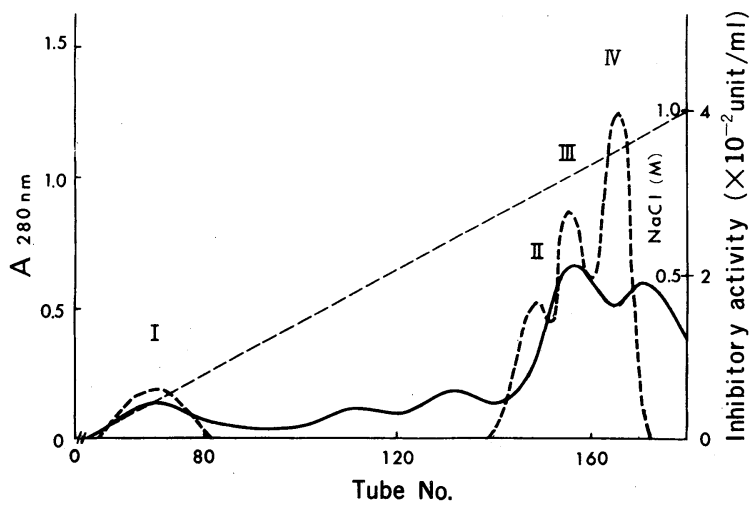

Fig. 1. Elution profile of crude trypsin inhibitor fraction on a CM-Sephadex C-25 column. The crude fraction $(0.8 \mathrm{~g})$ was applied to the column $(4.3 \times 100 \mathrm{~cm})$. Elution was carried out first with $200 \mathrm{ml}$ of $0.1 \mathrm{M}$ acetate buffer, $\mathrm{pH} 4.7$, and then with a linear gradient to $1.0 \mathrm{M} \mathrm{NaCl}$ at a flow rate of $73 \mathrm{ml} / \mathrm{hr}$. - , absorbancy at $280 \mathrm{~nm}$; -----, trypsin inhibitory activity; ----, $\mathrm{NaCl}$ concentration. 
labile proteins which were subsequently removed by centrifugation. Ammonium sulfate was added to the supernatant to $80 \%$ saturation to precipitate the fraction containing most of the inhibitory activity. The precipitate was dissolved in a minimum volume of $0.1 \mathrm{M}$ acetate buffer $(\mathrm{pH} 4.7)$. The resultant solution was then dialyzed against the same buffer, using cellulose tubing (VT 351, cut-off molecular weight 3,500). The dialysate (crude trypsin inhibitor) was applied to a CMSephadex C-25 column $(4.3 \times 100 \mathrm{~cm})$ previously equilibrated with $0.1 \mathrm{M}$ acetate buffer ( $\mathrm{pH}$ 4.7). The column was first washed with $200 \mathrm{ml}$ of the same buffer and the trypsin inhibitory active fractions were then eluted with the acetate buffer using a linear gradient of $\mathrm{NaCl}(0-1.0 \mathrm{M}), 10 \mathrm{~g}$ fractions being collected. The result of chromatographic fractionation of the crude trypsin inhibitor on a CM-Sephadex C25 column is presented in Fig. 1 which shows the presence of four active fractions designated as fractions I, II, III and IV. Total activities of the fractions were in the order of IV, III, II and I.

It was impossible to collect fraction I in a workable amount. Fractions II and III were dialyzed, lyophilized and further fractionated by chromatography on Sephadex G-75 and SP-Sephadex C-25, and four inhibitors were obtained from these fractions (22).

\section{Purification of fraction IV}

Fraction IV was further purified by chromatography on a Sephadex G-75 column (Fig. 2), and the main fraction eluted between tube nos. 47 and 55 was chromatographed on an SP-Sephadex C-25 column. As shown in Fig. 3, a symmetrical protein peak was obtained and was clearly associated with the

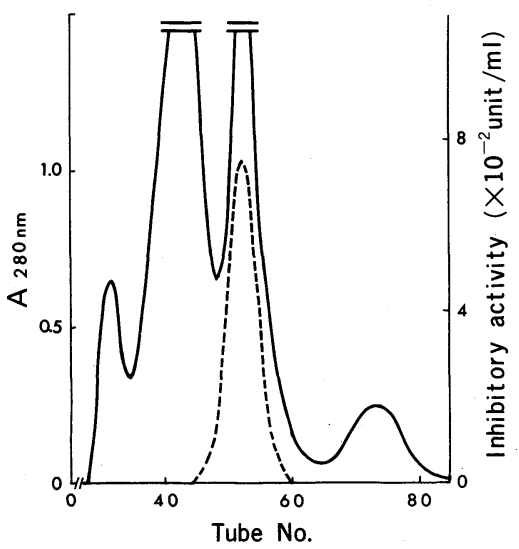

Fig. 2. Elution profile of fraction IV in gel filtration on a Sephadex G-75 column. Fraction IV $(140 \mathrm{mg})$ was dissolved in $7 \mathrm{ml}$ of $0.1 \mathrm{~m}$ Tris- $\mathrm{HCl}$ buffer, $\mathrm{pH} \mathrm{8.0.} \mathrm{The}$ solution was applied to the column $(1.8 \times 100 \mathrm{~cm})$ and the column was eluted with $0.1 \mathrm{M}$ Tris- $\mathrm{HCl}$ buffer $(\mathrm{pH} 8.0)$ at a flow rate of $12.7 \mathrm{ml} / \mathrm{hr}$. — , absorbancy at $280 \mathrm{~nm} ;-\cdots-.--$, trypsin inhibitory activity. 


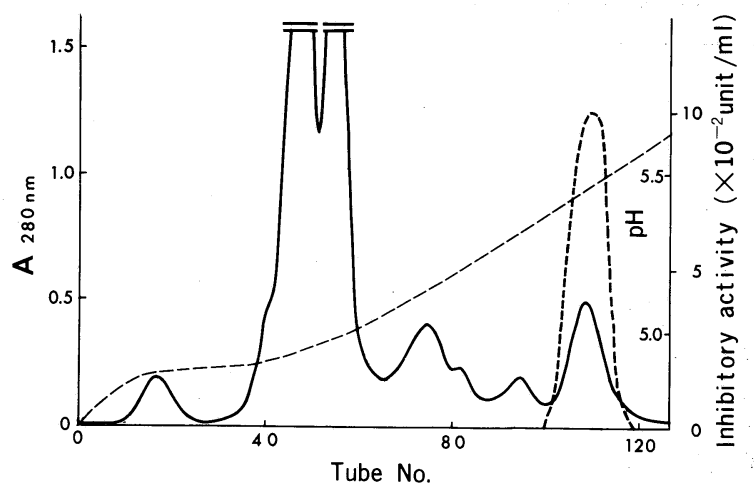

Fig. 3. Elution profile of the active fraction from Fig. 2 on an SP-Sephadex C-25 column. One hundred milligrams of the active fraction was dissolved in $7 \mathrm{ml}$ of $0.1 \mathrm{M}$ acetate buffer, $\mathrm{pH} 4.7$. The solution was applied to the column $(1.6 \times 25 \mathrm{~cm})$. Elution was carried out first with $200 \mathrm{ml}$ of $0.1 \mathrm{M}$ acetate buffer, $\mathrm{pH} 4.7$, and then with a linear gradient to $0.5 \mathrm{M}$ sodium acetate at a flow rate of $10 \mathrm{ml} / \mathrm{hr}$. at $280 \mathrm{~nm}$; ------, trypsin inhibitory activity; ----, $\mathrm{pH}$.

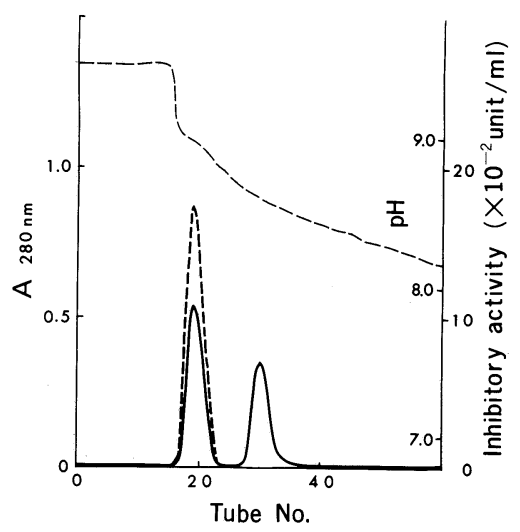

Fig. 4. Elution profile of the active fraction from Fig. 3 on a Polybuffer exchanger PBE 94 column. The active fraction $(10 \mathrm{mg})$ was dissolved in $5 \mathrm{ml}$ of $0.025 \mathrm{M}$ ethanolamine- $\mathrm{HCl}$ buffer, $\mathrm{pH} 9.5$. The solution was applied to the column $(1 \times 21.5$ $\mathrm{cm}$ ). Elution condition: start buffer $0.025 \mathrm{~m}$ ethanolamine- $\mathrm{HCl}, \mathrm{pH} 9.5$, elution buffer $0.0075 \mathrm{mmol} / \mathrm{pH}$ unit $/ \mathrm{ml}$ Pharmalyte $\mathrm{pH} 8-\mathrm{i} 0.5$ equilibrated to $\mathrm{pH} 8.0$. Flow rate: $31.4 \mathrm{ml} / \mathrm{hr}$.

inhibitory activity peak, but this fraction did not give a single band on disc electrophoresis on polyacrylamide gel. Further, the fraction was purified by chromatofocusing using Polybuffer exchanger PBE 94. The fractions indicated in Fig. 4 were combined, and ammonium sulfate was added to $100 \%$ saturation. The precipitate was collected by centrifugation and washed with saturated ammonium sulfate, dialyzed against water and lyophilized. The preparation was found to be

Vol. 28, No: 4, 1982 
Table 1. Summary of purification of WETI-I (from endosperm $1 \mathrm{~kg}$ ).

\begin{tabular}{lcccc}
\hline \multicolumn{1}{c}{ Step } & $\begin{array}{c}\text { Total protein } \\
(\mathrm{mg})\end{array}$ & $\begin{array}{c}\text { Total } \\
\text { unit }\end{array}$ & $\begin{array}{c}\text { Specific activity } \\
\text { (unit/mg protein) }\end{array}$ & $\begin{array}{c}\text { Yield } \\
(\%)\end{array}$ \\
\hline $\begin{array}{l}\text { Extract } \\
\text { Dialysate } \\
\text { 1st chromatography on } \\
\quad \text { CM-Sephadex C-25 column }\end{array}$ & $16,829.5$ & 131,270 & 7.8 & 100.0 \\
$\begin{array}{l}\text { 2nd chromatography on } \\
\quad \text { Sephadex G-75 column }\end{array}$ & $1,913.6$ & 113,050 & 14.3 & 86.1 \\
$\begin{array}{l}\text { 3rd chromatography on } \\
\quad \text { SP-Sephadex C-25 column }\end{array}$ & 11.4 & 46,837 & 41.7 & 35.7 \\
$\begin{array}{l}\text { 4th chromatography on } \\
\quad \text { Polybuffer exchanger }\end{array}$ & 3.2 & 41,489 & 212.8 & 31.6 \\
$\quad$ PBE 94 column & & 11,429 & $1,162.8$ & 10.1 \\
\hline
\end{tabular}

${ }^{\mathrm{a}}$ Protein $=$ nitrogen $\times 6.25$.

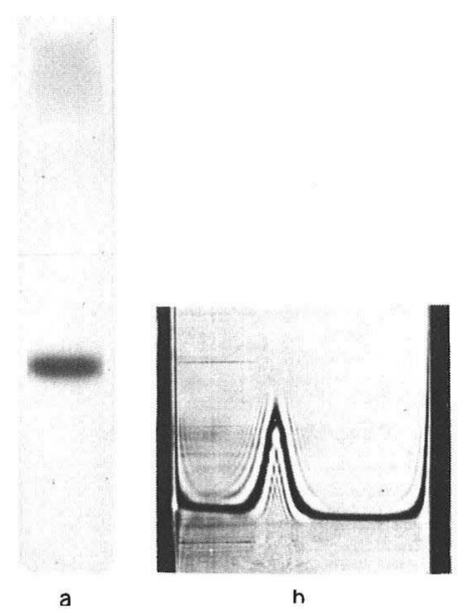

Fig. 5. Gel electrophoresis and velocity sedimentation pattern of WETI-I. a: Electrophoresis of the inhibitor was run on $10 \%$ gel using a buffer system described by Reinsfeld et al.(19). b: The pattern was obtained with the inhibitor at a concentration of $0.4 \%$ at $20^{\circ} \mathrm{C}$, the picture being taken $16 \mathrm{~min}$ after the reaching of a speed of $59,780 \mathrm{rpm}$.

electrophoretically homogeneous, giving a single band and hereafter denoted by "wheat endosperm trypsin inhibitor-I (WETI-I)." The summary of the purification is shown in Table 1.

Gel electrophoresis and velocity sedimentation of WETI-I

The homogeneity of the inhibitor was examined by disc electrophoresis and 


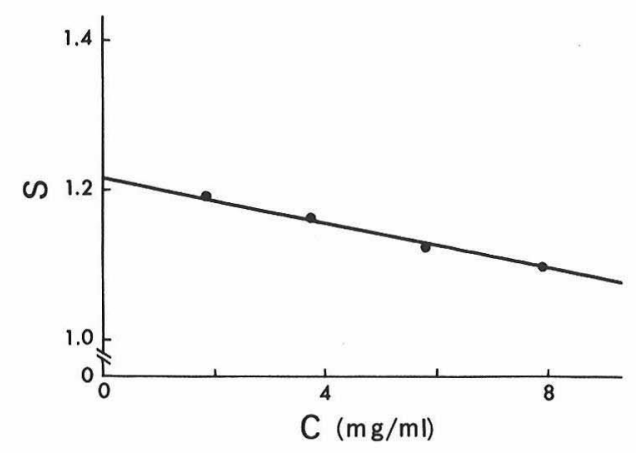

Fig. 6. Concentration dependence of sedimentation coefficient of WETI-I. Data were from a series of experiments as shown in Fig. 5b.

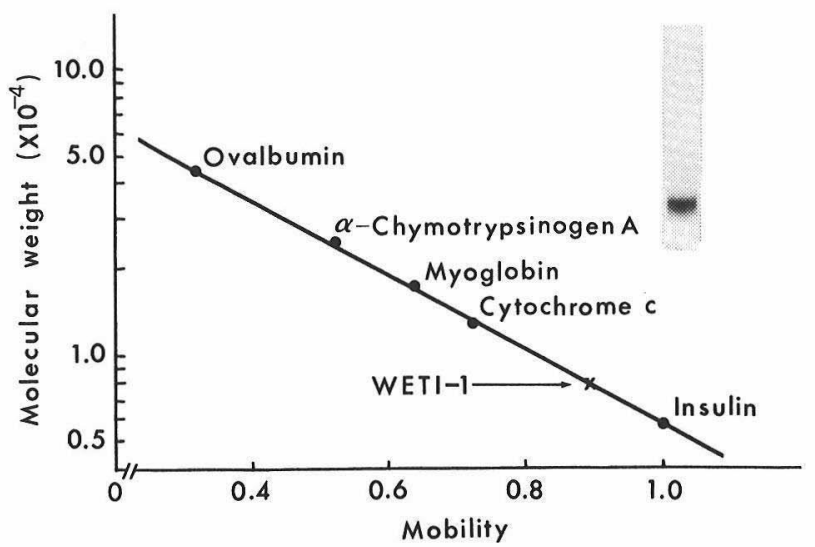

Fig. 7. Estimation of molecular weight of WETI-I by SDS-gel electrophoresis. Gel electrophoresis was carried out on $10 \%$ gel in $0.1 \mathrm{M}$ phosphate buffer $(\mathrm{pH} 7.1)$ containing $1 \%$ SDS. The samples and marker proteins were preincubated in phosphate buffer containing $1 \%$ SDS and $1.0 \%$ 2-mercaptoethanol at $60^{\circ} \mathrm{C}$ for $2 \mathrm{hr}$ prior to electrophoresis.

velocity sedimentation. WETI-I exhibited a sharp single band in gel electrophoresis and a symmetric sharp boundary of $1.2 \mathrm{~S}$ in velocity sedimentation (Figs. 5 and 6).

Isoelectric focusing of the inhibitor also gave only a single component, and the $\mathrm{p} I$ value was 9.35 .

Molecular weight of WETI-I

The molecular weight was estimated by SDS-gel electrophoresis in $0.1 \mathrm{M}$ phosphate buffer ( $\mathrm{pH} 7.1$ ) containing $1 \%$ SDS. Figure 7 shows the molecular weight vs. mobility plot from which the molecular weight of WETI-I approximates to 7,800 .

Vol. 28, No. 4, 1982 


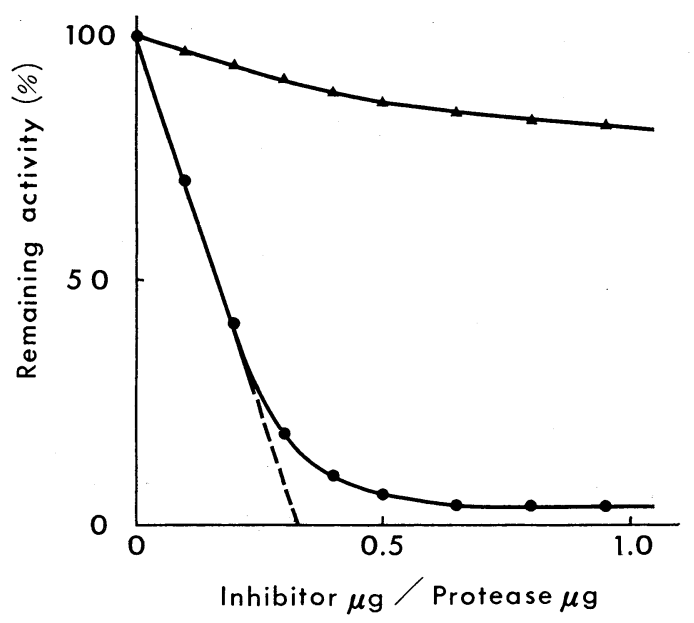

Fig. 8. Proteases inhibition by WETI-I. Experimental procedures (casein method) are described in the text. $\bullet$, trypsin; $\boldsymbol{\Delta}, \alpha$-chymotrypsin.

\section{Inhibitory activity}

The inhibitory activity of the inhibitor against trypsin and $\alpha$-chymotrypsin is shown in Fig. 8. The inhibitor possessed strong inhibitory activity against trypsin. Extrapolation of the linear portion of the curve to zero trypsin activity revealed that one $\mu \mathrm{g}$ of the inhibitor completely inactivated $3.06 \mu \mathrm{g}$ of trypsin when the activity of trypsin was assayed with casein as substrate and also inactivated $3.14 \mu \mathrm{g}$ of trypsin when BANA was used as substrate. Thus, the molecular weight was estimated to be 7,610 or 7,420 , assuming that $1 \mathrm{~mol}$ of the inhibitor inhibits $1 \mathrm{~mol}$ of trypsin (molecular weight 23,300). The values are in near agreement with the molecular weight determined by SDS-gel electrophoresis.

The inhibitor also inhibited $\alpha$-chymotrypsin but the inhibition did not show stoichiometrical behavior.

\section{Some other properties of WETI-I}

The inhibitor is a polypeptide composed solely of amino acids. While neutral sugar was detected in the early stages of purification, the final preparation was found to be free from neutral sugar and hexosamine.

Figure 9 shows the UV absorption spectra of WETI-I in $0.05 \mathrm{M}$ sodium phosphate buffer ( $\mathrm{pH} 6.0$ ) and in $0.1 \mathrm{M} \mathrm{NaOH}$. At $\mathrm{pH} 6.0$, the absorption maximum was $278 \mathrm{~nm}$ and the minimum at $247 \mathrm{~nm}$. The absorption coefficient, $E_{1 \mathrm{~cm}}^{1 \%}$, was calculated to be 11.68 at $278 \mathrm{~nm}$.

The amino acid composition of WETI-I is shown in Table 2. The inhibitor is rich in arginine and proline, and does not contain tryptophan. 


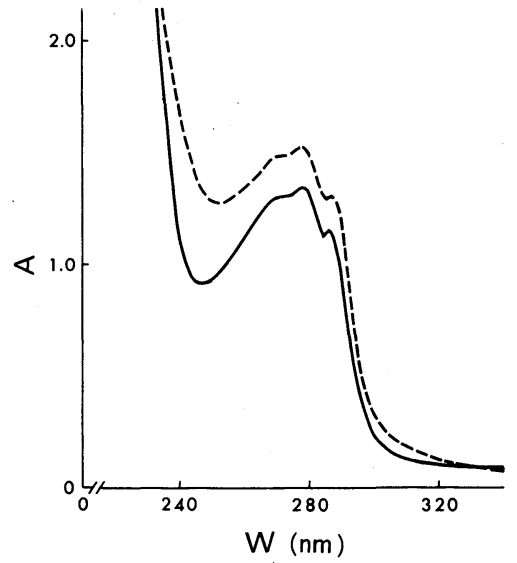

Fig. 9. UV absorption spectra of WETI-I. The inhibitor concentration was $0.1 \%$. in $0.05 \mathrm{M}$ phosphate buffer ( $\mathrm{pH} 6.0$ ); -----, in $0.1 \mathrm{M} \mathrm{NaOH}$ solution.

Table 2. Amino acid composition ${ }^{\mathrm{a}}$ of WETI-I.

\begin{tabular}{lcc}
\hline \multicolumn{1}{c}{ Amino acid } & $\begin{array}{c}\text { No. of residues } \\
\text { per molecule }\end{array}$ & Nearest integer \\
\hline Aspartic acid $^{\mathrm{b}}$ & 5.83 & 6 \\
Threonine $^{\mathrm{c}}$ & 6.32 & 6 \\
Serine $^{\mathrm{c}}$ & 3.68 & 4 \\
Glutamic acid $^{\text {Glycine }}$ & 5.70 & 6 \\
Alanine & 4.93 & 5 \\
Half-cystine & 4.56 & 5 \\
Valine $^{\mathrm{c}}$ & 6.25 & 6 \\
Methionine & 3.06 & 3 \\
Isoleucine $^{\text {Leucine }}$ & 4.08 & 4 \\
Tyrosine $^{\mathrm{d}}$ & 2.09 & 2 \\
Phenylalanine $^{\text {Lysine }}$ & 2.49 & 2 \\
Histidine $_{\text {Arginine }}$ & 1.94 & 2 \\
Proline $^{\text {Tryptophan }}{ }^{\mathrm{d}}$ & 2.09 & 2 \\
Total $_{\text {Molecular weight }}$ & 2.37 & 2 \\
& 2.02 & 8 \\
& 7.51 & 7 \\
\hline
\end{tabular}

${ }^{\text {a }}$ Average value from 24,48 and $72 \mathrm{hr}$ ' hydrolysates. ${ }^{\mathrm{b}}$ Calculated for a molecular weight of $7,800 .{ }^{\mathrm{c}}$ Extrapolated value to zero hour. ${ }^{\mathrm{d}}$ Determined spectrophotometrically. 


\section{DISCUSSION}

A trypsin inhibitor was isolated successively from wheat endosperm by extraction, heat-treatment, salting out and chromatographies. Chromatofocusing was used for the final purification, since a contaminated component could not be removed completely from the inhibitor purified by repeated ion-exchange chromatographies. The final purified inhibitor (WETI-I) was about 460 times more active than the crude extract. WETI-I was a polypeptide composed solely of amino acids, and amino acid analyses indicated that the inhibitor was rich in arginine and proline, and did not contain tryptophan. This composition is similar to the trypsin inhibitor isolated from wheat germ by Hochstrasser and Werle(6). However, WETI-I has a molecular weight of about 7,800, whereas the molecular weights of the trypsin inhibitors from wheat grain have been reported to be in the range of $10,000-38,500(6,7,10,11)$. Therefore, it is concluded that WETI-I has at present the lowest molecular weight among the trypsin inhibitors isolated from wheat endosperm, bran and germ. WETI-I inhibited trypsin and the inhibition showed stoichiometrical behavior, while it inhibited weakly $\alpha$-chymotrypsin. Shyamala and Lyman (5) isolated a trypsin inhibitor from wheat flour, which appears to have a low specific activity and does not inhibit $\alpha$-chymotrypsin. It should be noted that this inhibitor differs markedly from WETI-I in the chemical components, the specific activity for trypsin and the inhibition of $\alpha$-chymotrypsin. The $\mathrm{p} I$ value (9.35) indicates that WETI-I may be the most basic inhibitor among trypsin inhibitors from plant origin, the $\mathrm{p} I$ value of them being 8.07 for rice bran(23), 4.7 for eggplant (17) and 8.9 and 9.1 for potato (24).

\section{ADDENDUM}

During the preparation of this manuscript, a paper by Boisen and Djurtoft on a similar subject appeared (25).

\section{REFERENCES}

1) Learmonth, E. M., and Wood, J. C. (1960): A trypsin inhibitor in wheat flour. Chem. and Ind. (London), 51, 1569-1570.

2) Shyamala, G., Kennedy, B. M., and Lyman, R. L. (1961): Trypsin inhibitor in wholewheat flour. Nature, 192, 360 .

3) Learmonth, E. M., and Wood, J. C. (1963): A trypsin inhibitor in wheat flour. Cereal Chem., 40, 61-65.

4) Petrucci, T., Tomasi, M., Cantagalli, P., and Silano, V. (1974): Comparison of wheat albumin inhibitors of $\alpha$-amylase and trypsin. Phytochemistry, 13, 2487-2495.

5) Shyamala, G., and Lyman, R. L. (1964): The isolation and purification of a trypsin inhibitor from wholewheat flour. Can. J. Biochem., 42, 1825-1832.

6) Hochstrasser, K., and Werle, E. (1969): Plant protease inhibitors. III. The purification of trypsin inhibitors from germ of wheat and rye, and the localization of the active centres. Hoppe-Seyler's Z. Physiol. Chem., 350, 249-254. 
7) Chang, C. R., and Tsen, C. C. (1981): Isolation of trypsin inhibitors from rye, triticale, and wheat samples. Cereal Chem., 58, 207-210.

8) Chang, C. R., and Tsen, C. C. (1981): Characterization and heat stability of trypsin inhibitors from rye, tritical, and wheat samples. Cereal Chem., 58, 211-213.

9) Mitsunaga, T. (1974): Some properties of protease inhibitors in wheat grain. J. Nutr. Sci. Vitaminol., 20, 153-159.

10) Mitsunaga, T. (1979): Isolation and characterization of trypsin inhibitors from wheat germ. J. Nutr. Sci. Vitaminol., 25, 43-52.

11) Mitsunaga, T., and Shimizu, M. (1982): Isolation and partial characterization of a trypsin inhibitor from wheat bran. Nippon Nogeikagaku Kaishi (in Japanese), 56, 7-12.

12) Lowry, O. H., Rosebrough, N. J., Farr, A. L., and Randall, R. J. (1951): Protein measurement with the Folin phenol reagent. J. Biol. Chem., 193, 265-275.

13) Official Methods of Analysis of the Association of Official Analytical Chemists, ed. by Horwitz, W., Association of Official Analytical Chemists, Washington, D. C., pp. 16, 858 (1970).

14) Dubois, M., Gilles, K. A., Hamilton, J. K., Rebers, P. A., and Smith, F. A. (1956): Carbohydrate was determined by the phenol sulfuric acid method. Anal. Chem., 28, 350-357.

15) Goodwin, T. W., and Morton, R. A. (1946): The spectrophotometric determination of tyrosine and tryptophan in proteins. Biochem. J., 40, 628-632.

16) Erlanger, B. F., Kokwsky, N., and Cohen, W. (1961): Preparation and properties of two new chromogenic substances of trypsin. Arch. Biochem. Biophys., 95, 271-278.

17) Kanamori, M., Ibuki, F., Tashiro, M., Yamada, M., and Miyoshi, M. (1975): Occurrence of a trypsin inhibitor in eggplant exocarps. J. Nutr. Sci. Vitaminol., 21, 421428.

18) Chase, T., Jr., and Shaw, E. (1970): Titration of trypsin, plasmin, and thrombin with $p$ nitrophenyl- $p^{\prime}$-guanidinobenzoate $\mathrm{HCl}$, in Methods in Enzymology, Vol. 19, ed. by Perlmann, G. E., and Lorand, L., Academic Press, New York, pp. 20-27.

19) Reinsfeld, R. A., Lewis, U. J., and Williams, D. E. (1962): Disk electrophoresis of basic proteins and peptides on polyacrylamide gels. Nature, 195, 281-282.

20) Shapiro, A. L., Vinnela, E., and Maziel, J. V., Jr. (1967): Molecular weight estimation of polypeptide chains by electrophoresis in SDS-polyacrylamide gels. Biochem. Biophys. Res. Commun., 28, 815-820.

21) Weber, K., and Osborn, M. (1969): The reliability of molecular weight determinations by dodecyl sulfate-polyacrylamide gel electrophoresis. J. Biol. Chem., 244, 4406-4412.

22) Kimura, Y., Shimizu, M., and Nunoura, H. (1981): Partial purification and some properties of minor protease inhibitors in wheat endosperm. Shokumotsugaku Kaishi (Kyoto Women's Univ., in Japanese), 36, 35-39.

23) Tashiro, M., and Maki, Z. (1979): Purification and characterization of a trypsin inhibitor from rice bran. J. Nutr. Sci. Vitaminol., 25, 255-264.

24) Iwasaki, T., Kiyohara, T., and Yoshikawa, M. (1972): Chemical and physicochemical characterization of two different types of protease inhibitors (inhibitors II-a and II-b) from potatoes. J. Biochem., 72, 1029-1035.

25) Boisen, S., and Djurtoft, R. (1981): Trypsin inhibitor from wheat endosperm: Purification and characterization. Cereal Chem., 58, 460-463. 